\title{
RESPONSE OF TAGETES PATULA PLANTS TO FOLIAR APPLICATION OF POTASSIUM SILICATE AND SEAWEED EXTRACT UNDER VARIOUS IRRIGATION INTERVALS
}

\author{
A.M. Ayyat ${ }^{*}$ and M.A.M Abdel-Mola ${ }^{* *}$ \\ * Dept. of Medicinal and Aromatic Plants, Fac. Agric., Beni-Suef Univ., Egypt \\ ** Dept. of Horticulture (Ornamental Plants), Fac. Agric., Beni-Suef Univ., Egypt
}

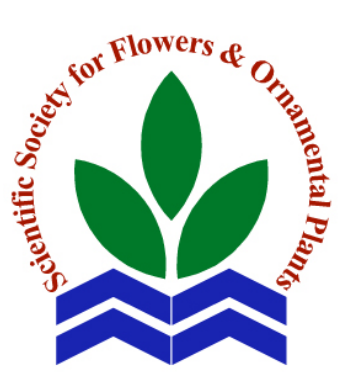

Scientific J. Flowers \& Ornamental Plants, 7(4):513-526 (2020).

Received:

$2 / 11 / 2020$

Accepted:

$28 / 11 / 2020$

\begin{abstract}
This study was carried out during the two successive seasons of 2018 and 2019 at Somosta, Beni-Suef Governorate, Egypt, to evaluate the effect of irrigation intervals, foliar application of potassium silicate and seaweed extract on vegetative and flowering growth parameters and essential oil percentage of Tagetes patula plants. Plant height $(\mathrm{cm})$, number of branches, stem diameter $(\mathrm{mm})$, leaf area $\left(\mathrm{cm}^{2}\right)$, plant fresh and dry weights $(\mathrm{g})$, flowering date, number of inflorescences/plant, inflorescence diameter $(\mathrm{cm})$, inflorescence fresh and dry weights/plant (g) and vase life/days were significantly decreased with rising intervals of irrigation. Irrigation regime of four days interval gave the earliest flowering. The results cleared that, foliar applications of seaweeds extract at $3 \mathrm{ml} / 1$ and $5 \mathrm{ml} / 1$, potassium silicate at $3 \mathrm{ml} / 1$ and $5 \mathrm{ml} / 1$ significantly affected all studied parameters compared with control. The magnitude of increase is more pronounced by applying combination between potassium silicate and seaweed extract treatments at the high concentration. The most pronounced effect for the interaction was that found between potassium silicate at 5 $\mathrm{ml} / \mathrm{l}$ plus seaweeds extract at $5 \mathrm{ml} / \mathrm{l}$ when plants irrigated every one or two days where the highest vegetative and flowering growth parameters and essential oil percentage were recorded in both seasons. So, it is advisable, to reduce the effect of drought stress, treating tagetes plants with high concentration of potassium silicate and/or seaweed extract each at $5 \mathrm{ml} / 1$.
\end{abstract}

Key words: Tagetes patula, irrigation intervals, potassium silicate, seaweed extract.

\section{INTRODUCTION}

The tagetes genus consists of around 4050 species and follows to the Asteraceae family (Lawrence, 1985). It has a pretty commercial flower that is gaining status because of its wide range of adaptation and increasing demand in wide area of the world (Asif, 2008). It is also one of the most important herbaceous ornamental with aromatic scent. It is highly ornamental in flowerbeds for mass display, pots, borders and may be used effectively in window and porch boxes (Nau, 1997). The flowers are used in medicines and pharmaceuticals, processed foods, confectionery and in the poultry industry. As an antiparasitic, antispasmodic, antibiotic, antimicrobial and antiseptic, its essential oil is successful (Chowdhury et al., 2009).

Drought is considered to be one of the most significant factors restricting the development of plants in arid and semiarid zones (Ehdaie, 1995), where a wide range of temperature variability and climate changes are encountered in certain areas. Under such conditions, lower yields and 
lower efficiency of water use occur, particularly in the context of water volume evaporation from year to year (Owies et al., 2000).

Silicon (Si) is one of the most important sources of chemical elements in nature (Chen et al., 2010) and plant growth micronutrients (Regina and Katarzyna, 2011). It is well known that $\mathrm{Si}$ is involved in plant tolerance to several stress factors, including soil silicon helping plants to remain alive under conditions of water scarcity and reducing transpiration in cells with high silicon concentration. Silicon alleviates the harmful effects on different abiotic stresses such as drought stress, salt stress, radiation damage, metal toxicity, high temperature, nutrient imbalance, freezing and chilling, etc. (Ma, 2004 and Liang et al., 2007).

Seaweed extracts (SWE) are emerging as industrial biostimulants. Formulations for use as factors that foster plant growth and a tool for enhancing salinity, heat and drought tolerance. In order to improve resistance under stress, algal extracts target a variety of pathways. Red, green and brown macro algae are seaweeds that account for 10 percent of marine productivity (Battacharyya et al., 2015). Seaweed offers an outstanding source of bioactive compounds such as carotenoids, protein, essential fatty acids, vitamins, amino acids, minerals and substances that promote growth (Bhaskar and Miyashita, 2005).

The aim of this study was to investigate the impact of irrigation intervals and the use of both potassium silicate, seaweed extract as foliar-spray application and their combination on vegetative, flowering and percentage of essential oil on marigold (Tagetes patula, L.) plant.

\section{MATERIALS AND METHODS}

The present investigation study was conducted at Somosta, Beni-Suef Governorate, Egypt, during the two successive seasons of 2018 and 2019.
The seeds of Tagetes patula, L. were obtained from Sids Agricultural Research Station, Medicinal and Aromatic Plants Dept. of Hort. Res. Inst., Agric. Res. Center, Egypt. Seeds were sown in the nursery on February $15^{\text {th }}$ in both growing seasons. Uniform seedlings of 45 days old and $10 \mathrm{~cm}$ height were transplanted into plastic pots ( 30 $\mathrm{cm})$ which filled with $10 \mathrm{~kg}$ of clayey soil and contained one seedling. The constituents and characteristics of the experimental soil are shown in Table (a) (Jackson, 1973).

\section{Experimental treatments and design:}

A complete randomized block design following the split plot arrangement, in three replicates, was executed in this experiment with four irrigation intervals treatments (daily, every two days, every three and four days) in the main plots (A), after two weeks from transplanting, plants were irrigated with $300 \mathrm{ml} /$ pot and six treatments (control, potassium silicate at $3 \mathrm{ml} / \mathrm{l}$ (PS1), potassium silicate at $5 \mathrm{ml} / 1$ (PS2), seaweed at $3 \mathrm{ml} / 1$ (SWE1), seaweed at $5 \mathrm{ml} / 1$ (SWE2), and potassium silicate at $5 \mathrm{ml} / 1$ plus seaweed at 5 $\mathrm{ml} / \mathrm{l}$ (PS2 + SWE2) in the sub-plots (B). Seaweeds extract composition, (Algeser product from Shoura Chemicals Company), is shown in Table (b) according to (James, 1994) and potassium silicate $(25 \% \mathrm{Si}$ and $10 \% \mathrm{~K}_{2} \mathrm{O}$ ) were sprayed three times at two weeks interval after $7^{\text {th }}$ April until runoff during each growing season. Triton B $(0.05 \%)$ was applied to all the SWE and potassium silicate as a wetting agent.

\section{Growth characteristics:}

The vegetative growth parameters were included; plant height $(\mathrm{cm})$, number of branches/plant, stem diameter $(\mathrm{mm})$, leaf area $\left(\mathrm{cm}^{2}\right)$, plant fresh weight $(\mathrm{g})$ and plant dry weight $(\mathrm{g})$. While the flowering data included; flowering date (number of days from transplantation to the first apparent flowering bud), number of inflorescences/plant, inflorescence fresh weight $(\mathrm{g})$, diameter of inflorescence $(\mathrm{cm})$, inflorescence dry weight $(\mathrm{g})$ and vase life (days). 
Table a. Some physical and chemical characteristics of the experimental soil.

\begin{tabular}{|c|c|c|c|c|c|c|c|}
\hline $\begin{array}{c}\text { Organic } \\
\text { matter \% }\end{array}$ & $\mathrm{CaCO}_{3} \%$ & Sand \% & Silt \% & Clay \% & Soil type & pH & $\operatorname{ECe}\left(\mathrm{dSm}^{-1}\right)$ \\
\hline 1.35 & 1.75 & 26 & 35 & 39 & Clayey loam & 7.4 & 3.2 \\
\hline \multicolumn{4}{|c|}{ Soluble ions (meq/l) } & \multicolumn{4}{|c|}{ Available elements } \\
\hline $\mathrm{HCO}^{3-}$ & 2.5 & $\mathrm{Mg}^{2+}$ & 6.02 & & $\mathrm{~N}$ & $\mathrm{ppm}$ & \\
\hline $\mathrm{Cl}^{-}$ & 9.3 & $\mathrm{Na}^{+}$ & 4.55 & & $\mathrm{P}$ & ppm & \\
\hline $\mathrm{SO}^{2-}$ & 10.7 & $\mathrm{~K}^{+}$ & 0.32 & & $\mathrm{~K}$ & $\mathrm{ppm}$ & \\
\hline $\mathrm{Ca}^{2+}$ & 10.9 & & & & & & \\
\hline
\end{tabular}

Table b. Analysis of seaweeds extract (according to James, 1994).

\begin{tabular}{cccc}
\hline Character & Values & Character & Values \\
\hline Moisture \% & 6.0 & $\mathrm{Mg} \%$ & $0.5-0.9$ \\
Protein \% & $6-8$ & $\mathrm{Ca} \%$ & $0.2-1.5$ \\
Aliginic acid \% & $10-20$ & $\mathrm{Zn} \mathrm{ppm}$ & $10-100$ \\
Mannitol \% & $4-7$ & $\mathrm{Mn} \mathrm{ppm}$ & $5-12$ \\
Carbohydrate \% & $35-50$ & $\mathrm{Fe} \mathrm{ppm}$ & $50-200$ \\
Organic matter \% & $45-60$ & $\mathrm{~B} \mathrm{ppm}$ & $20-100$ \\
Inorganic matter \% & $45-60$ & $\mathrm{Cu} \mathrm{ppm}$ & $1.0-6.0$ \\
Total N \% & $1.0-1.5$ & Mo ppm & $1-5$ \\
$\mathrm{P} \%$ & $0.02-0.09$ & IAA\% & 0.03 \\
$\mathrm{~S} \%$ & $3-9$ & Cytokinins & 0.02 \\
$\mathrm{~K} \%$ & $1.0-1.2$ & ABA $\%$ & 0.01 \\
\hline
\end{tabular}

Flowers were harvested at the optimal stage of growth (at least 3 rows of petals fully expanded) between 7:00 am and 10:00 am. The lower half of the stem was separated from its leaves and the stems were cut to a consistent length of $35 \mathrm{~cm}$, within 5 minutes of being cut, flowers were then put into glass container vases. Vases were filled with tap water and the containers were held at room temperature. Vase life was terminated on the basis of 50 percent wilted or brown petals as defined by Dole et al. (2013).

\section{Essential oil percentage:}

According to Guenther (1961), essential oil percentage of tagetes was extracted for 2 hours by water distillation of $20 \mathrm{~g}$ of aerial parts of plant. The essential oil extracted was dehydrated with anhydrous sodium sulphate.

$$
\text { Essential oil \%= } \frac{\begin{array}{c}
\text { volume oil in graduated } \\
\text { tube } \times 100
\end{array}}{\text { sample weight }(20 \mathrm{~g})}
$$

\section{Statistical analysis:}

Statistical analysis of variance was used to analyze the experiment data using
MSTAT-C (1986). The least significant difference (L.S.D.) test was used to compare the means of the gathered data at the level of $5 \%$, as mentioned by Mead et al. (1993).

\section{RESULTS AND DISCUSSION}

\section{Vegetative growth aspects:}

Regarding the main impact on the plant growth parameters of irrigation intervals, data presented in Tables ( 1 and 2) declared that plant height, number of branches, stem diameter, plant fresh and dry weights and leaf area of tagetes plants were significantly decreased with increasing irrigation intervals in both seasons. The sharp reduction of plant growth parameters was found under irrigation interval at (4) days in both seasons. Under irrigation interval at 4-days the estimated reduction percentages in plant height, number of branches, stem diameter, leaf area and plant fresh and dry weights were 21.38 and $22.67,30.72$ and 34.59 , 20.00 and $23.38,34.79$ and $32.75,23.36$ and $23.78,30.37$ and 29.92 compared to the control treatment for the two growing seasons, respectively. These results are in coincidence with those of Al-Ubaydi et al. 
Table 1. Effect of irrigation intervals, potassium silicate and seaweed extract treatments on plant height $(\mathrm{cm})$, number of branches and stem diameter $(\mathrm{mm})$ of Tagetes patula plants during 2018 and 2019 seasons.

\begin{tabular}{ccccccccccc}
\hline $\begin{array}{c}\text { Potassium } \\
\text { silicate and } \\
\text { seaweed } \\
\text { treatments } \\
\text { (B) }\end{array}$ & A1 & A2 & A3 & A4 & Mean & A1 & A2 & A3 & A4 & Mean \\
& & First season (2018) & & & Second season (2019) &
\end{tabular}

\begin{tabular}{lcccccccccc}
\hline & \multicolumn{7}{c}{ Plant height (cm) } \\
Control (water) & 52.7 & 50.5 & 45.7 & 41.3 & 47.6 & 53.7 & 50.2 & 48.6 & 39.4 & 48.0 \\
PS1 & 55.3 & 51.1 & 47.1 & 43.2 & 49.2 & 54.6 & 52.8 & 49.2 & 42.4 & 49.8 \\
PS2 & 57.1 & 52.7 & 49.6 & 44.5 & 51.0 & 56.5 & 55.7 & 50.5 & 44.7 & 51.9 \\
SWE1 & 56.2 & 52.4 & 48.4 & 44.2 & 50.3 & 55.9 & 54.3 & 51.3 & 43.3 & 51.2 \\
SWE2 & 57.7 & 53.2 & 49.5 & 46.7 & 51.8 & 58.3 & 56.4 & 55.2 & 45.6 & 53.9 \\
PS2 + SWE2 & 60.4 & 56.7 & 52.3 & 47.3 & 54.2 & 62.4 & 61.3 & 59.7 & 48.3 & 57.9 \\
Mean (A) & 56.6 & 52.7 & 48.8 & 44.5 & & 56.9 & 55.1 & 52.4 & 44.0 & \\
L.S.D. at 5\% & A: 3.2 & & B: 2.4 & AB: 4.8 & A: 1.9 & B: 2.1 & AB: 4.2 \\
\hline & & & & Number of branches & & & & \\
Control (water) & 14.3 & 13.7 & 10.5 & 8.7 & 11.8 & 13.7 & 12.2 & 11.3 & 7.5 & 11.2 \\
PS1 & 14.7 & 13.3 & 11.7 & 9.6 & 12.3 & 15.3 & 12.5 & 11.7 & 8.2 & 11.9 \\
PS2 & 15.7 & 13.6 & 13.7 & 10.7 & 13.4 & 16.5 & 14.3 & 13.3 & 11.5 & 13.9 \\
SWE1 & 15.2 & 14.1 & 13.4 & 10.5 & 13.3 & 15.7 & 13.1 & 12.8 & 10.9 & 13.1 \\
SWE2 & 15.5 & 14.7 & 14.1 & 11.3 & 13.9 & 16.3 & 15.4 & 13.7 & 11.7 & 14.3 \\
PS2 + SWE2 & 16.2 & 16.7 & 14.3 & 13.0 & 15.1 & 17.7 & 15.7 & 15.3 & 12.5 & 15.3 \\
Mean (A) & 15.3 & 14.4 & 13.0 & 10.6 & & 15.9 & 13.9 & 13.0 & 10.4 & \\
L.S.D. at 5\% & A: 1.1 & B: 0.7 & AB: 1.4 & A: 1.5 & B: 0.9 & AB: 1.8 \\
\hline
\end{tabular}

Stem diameter $(\mathrm{mm})$

$\begin{array}{lllllllllll}\text { Control (water) } & 7.3 & 6.9 & 6.2 & 5.4 & 6.5 & 6.9 & 6.7 & 5.9 & 5.1 & 6.2 \\ \text { PS1 } & 7.2 & 7.1 & 6.7 & 5.7 & 6.7 & 7.4 & 7.1 & 6.2 & 5.5 & 6.6 \\ \text { PS2 } & 7.5 & 7.3 & 6.9 & 6.1 & 7.0 & 7.7 & 7.3 & 6.5 & 5.8 & 6.8 \\ \text { SWE1 } & 7.4 & 7.6 & 6.5 & 5.9 & 6.9 & 7.5 & 7.8 & 6.3 & 6.1 & 6.9 \\ \text { SWE2 } & 7.7 & 7.9 & 6.8 & 6.4 & 7.2 & 8.2 & 7.8 & 6.6 & 6.2 & 7.2 \\ \text { PS2 + SWE2 } & 8.1 & 7.7 & 7.3 & 6.6 & 7.4 & 8.4 & 8.1 & 7.4 & 6.7 & 7.6 \\ \text { Mean (A) } & 7.5 & 7.4 & 6.7 & 6.0 & & 7.7 & 7.5 & 6.5 & 5.9 & \end{array}$

L.S.D. at 5\%

A: $0.6 \quad$ B: 0.4

AB: 0.8

A: 0.9

B: 0.3

AB: 0.6

A1: daily irrigation, A2: irrigating every two days, A3: every three days and A4: every four days. PS1: potassium silicate at $3 \mathrm{ml} / \mathrm{l}$, PS2: potassium silicate at $5 \mathrm{ml} / \mathrm{l}, \mathrm{SWE1}$ : seaweed at $3 \mathrm{ml} / \mathrm{l}, \mathrm{SWE2}$ : seaweed at $5 \mathrm{ml} / \mathrm{l}$, and PS2 + SWE2: potassium silicate at $5 \mathrm{ml} / \mathrm{l}+$ seaweed at $5 \mathrm{ml} / \mathrm{l}$. 
Table 2. Effect of irrigation intervals, potassium silicate and seaweed extract treatments on leaf area $\left(\mathrm{cm}^{2}\right)$ and plant fresh and dry weights $(\mathrm{g})$ of Tagetes patula plants during 2018 and 2019 seasons.

\begin{tabular}{|c|c|c|c|c|c|c|c|c|c|c|}
\hline \multirow{3}{*}{$\begin{array}{c}\text { Potassium } \\
\text { silicate and } \\
\text { seaweed } \\
\text { treatments } \\
\text { (B) }\end{array}$} & \multicolumn{10}{|c|}{ Irrigation intervals (A) } \\
\hline & A1 & $\mathbf{A 2}$ & $\mathbf{A 3}$ & A4 & Mean & A1 & $\mathbf{A 2}$ & $\mathbf{A 3}$ & A4 & Mean \\
\hline & \multicolumn{5}{|c|}{ First season (2018) } & \multicolumn{5}{|c|}{ Second season (2019) } \\
\hline \multicolumn{11}{|c|}{ Leaf area $\left(\mathrm{cm}^{2}\right)$} \\
\hline Control (water) & 4.82 & 4.45 & 3.64 & 3.11 & 4.01 & 5.26 & 4.72 & 3.85 & 3.25 & 4.27 \\
\hline PS1 & 5.14 & 4.57 & 3.69 & 3.42 & 4.21 & 5.36 & 4.93 & 4.09 & 3.54 & 4.48 \\
\hline PS2 & 5.58 & 4.95 & 4.15 & 3.65 & 4.58 & 5.72 & 5.45 & 4.38 & 4.05 & 4.90 \\
\hline SWE1 & 5.43 & 4.72 & 3.98 & 3.50 & 4.41 & 5.65 & 5.15 & 4.32 & 3.77 & 4.72 \\
\hline SWE2 & 5.75 & 5.35 & 4.62 & 3.77 & 4.87 & 6.08 & 5.76 & 4.81 & 4.15 & 5.20 \\
\hline PS2 + SWE2 & 6.22 & 6.10 & 5.13 & 4.05 & 5.38 & 6.35 & 6.17 & 5.23 & 4.42 & 5.54 \\
\hline Mean (A) & 5.49 & 5.02 & 4.20 & 3.58 & & 5.74 & 5.36 & 4.45 & 3.86 & \\
\hline L.S.D. at 5\% & \multicolumn{2}{|c|}{ A: 0.35} & B: 0.43 & \multicolumn{2}{|c|}{ AB: 0.86} & \multicolumn{2}{|c|}{ A: 0.27} & B: 0.61 & \multicolumn{2}{|c|}{ AB: 1.22} \\
\hline \multicolumn{11}{|c|}{ Plant fresh weight (g) } \\
\hline Control (water) & 68.5 & 66.8 & 62.3 & 52.3 & 62.5 & 65.4 & 64.2 & 60.5 & 47.2 & 59.3 \\
\hline PS1 & 72.1 & 67.4 & 65.7 & 55.6 & 65.2 & 67.7 & 66.7 & 62.3 & 49.7 & 61.6 \\
\hline PS2 & 77.8 & 73.6 & 66.4 & 57.4 & 68.8 & 69.5 & 68.4 & 65.5 & 53.2 & 64.2 \\
\hline SWE1 & 75.3 & 70.7 & 64.8 & 56.2 & 66.8 & 70.2 & 67.5 & 64.7 & 52.4 & 63.7 \\
\hline SWE2 & 78.7 & 74.5 & 69.3 & 62.4 & 71.2 & 76.3 & 74.7 & 68.6 & 58.6 & 69.6 \\
\hline PS2 + SWE2 & 84.6 & 80.7 & 76.4 & 66.7 & 77.1 & 79.8 & 78.3 & 72.4 & 65.7 & 74.1 \\
\hline Mean (A) & 76.2 & 72.3 & 67.5 & 58.4 & & 71.5 & 70.0 & 65.7 & 54.5 & \\
\hline L.S.D. & \multicolumn{2}{|c|}{ A: 3.3} & B: 2.6 & \multicolumn{2}{|c|}{ AB: 5.2} & \multicolumn{2}{|c|}{ A: 2.1} & B: 1.8 & \multicolumn{2}{|c|}{ AB: 3.6} \\
\hline \multicolumn{11}{|c|}{ Plant dry weight (g) } \\
\hline Control (water) & 11.7 & 11.3 & 10.6 & 8.4 & 10.5 & 10.8 & 10.5 & 9.7 & 7.8 & 9.7 \\
\hline PS1 & 12.5 & 11.5 & 10.9 & 8.7 & 10.9 & 11.4 & 11.0 & 10.4 & 8.3 & 10.3 \\
\hline PS2 & 13.7 & 12.7 & 11.8 & 9.3 & 11.9 & 13.2 & 12.7 & 11.3 & 9.7 & 11.7 \\
\hline SWE1 & 13.1 & 12.4 & 11.3 & 9.1 & 11.5 & 12.7 & 11.5 & 10.7 & 8.7 & 10.9 \\
\hline SWE2 & 14.4 & 13.6 & 12.4 & 10.2 & 12.7 & 13.7 & 12.4 & 11.6 & 9.4 & 11.8 \\
\hline PS2 + SWE2 & 15.7 & 14.0 & 13.4 & 10.5 & 13.4 & 14.2 & 13.2 & 12.5 & 9.7 & 12.4 \\
\hline Mean (A) & 13.5 & 12.6 & 11.7 & 9.4 & & 12.7 & 11.9 & 11.0 & 8.9 & \\
\hline
\end{tabular}

L.S.D. at $5 \%$

A: 0.7

B: 1.1

$\mathrm{AB}: 2.2$

A: 0.4

B: 0.8

AB: 1.6

A1: daily irrigation, A2: irrigating every two days, A3: every three days and A4: every four days. PS1: potassium silicate at $3 \mathrm{ml} / \mathrm{l}$, PS2: potassium silicate at $5 \mathrm{ml} / \mathrm{l}$, SWE1: seaweed at $3 \mathrm{ml} / \mathrm{l}, \mathrm{SWE2}$ seaweed at $5 \mathrm{ml} / \mathrm{l}$, and PS2 + SWE2: potassium silicate at $5 \mathrm{ml} / \mathrm{l}+$ seaweed at $5 \mathrm{ml} / \mathrm{l}$. 
(2017) and Hussein et al. (2011). Water stress normally negatively affects plant growth and development, it can decrease plant height by decreasing the enlargement and division of cells (Manivannan et al., 2007 and Yazdani et al., 2007). By decreasing the available water content, drought stress will decrease plant dry weight, thereby decreasing leaf area and number as well as plant height (Ahmadi Azar et al., 2015).

Data presented in Tables (1 and 2) show the effect of foliar application of potassium silicate, SWE and their combinations in the highest concentrations on the growth parameters namely plant height, number of branches, stem diameter, leaf area and plant fresh and dry weights in both seasons. The obtained data proved that all vegetative growth characters were significantly enhanced due to these abovementioned treatments compared to untreated plants in the two seasons. The highest values concerning these characters were resulted from the treatment of combination between seaweed extract and potassium silicate at high concentration. In agreement with these results concerning foliar application of silicon were those of Moustafa et al. (2018) on Moringa oleifera. The role of silicon in enhancing plant growth is through the promotion of beneficial plant physiological processes (Korndörfer and Lepsch, 2001). It gives plants resistance to multiple stresses and is effective on controlling various pests and diseases caused by both fungi and bacteria (Ma, 2004). It plays a major role in plant stimulation of antioxidant enzymes (Liang et al., 2007) and in improving the status of plant water (Romero et al., 2006). In addition, Jugal and Ramani (2017) reported that $\mathrm{Si}$ plays a crucial role in improving the efficiency of nitrogen usage and distribution of ions.

Seaweed extract has resulted in a pronounced growth increase. This increase may be due to the existence of certain biochemical compounds such as growth regulators, organic components, macro components and micro components in seaweed extract that may be needed for the induction of antioxidant enzymes responsible for reducing the levels of reactive oxygen species (ROS). The promoting effect of the application of seaweed extract in tagetes plants were found to be similar with those obtained by (Abdou et al., 2018) on gladiolus plants, they found that vegetative growth parameters increased by seaweed extract treatments as compared to control. These findings may be due to the beneficial effect of the availability of naturally occurring nutrients in seaweed extracts, plant growth hormones (auxins, cytokinines and gibberellins) as well as other plant biostimulants, such as amino acids, vitamins that could sustain photosynthetic rates, increase plant resistance, delay plant senescence and regulate cell division (Strick et al., 1997 and Hemida et al., 2015).

The interaction between interval irrigation in combination with potassium silicate and seaweed treatments or both of them in the high level was not significant, in the two seasons, for each of plant height, stem diameter and branch number and plant fresh weight except for the 4 days interval irrigation as shown in Table (1 and 2). The best overall results, for the six vegetative growth traits were obtained due to supplying plants with dual dose of seaweed at $5 \mathrm{ml} / \mathrm{l}$ plus potassium silicate $5 \mathrm{ml} / \mathrm{l}$, in combination with interval irrigation treatments except for plant height and fresh weight of plant in the 4 days interval irrigation.

\section{Flowering aspects:}

All flowering aspects of tagetes plants were affected by irrigation intervals. Data presented in Tables (3 and 4) illustrated that increasing the irrigation intervals decreased flowering date, number of inflorescences/plant, inflorescence diameter $(\mathrm{cm})$, inflorescence fresh and dry weight $(\mathrm{g})$ and vase life by 15.06 and $17.44 \%, 37.86$ and $30.07 \%, 29.73$ and $25.71 \%, 31.28$ and $24.23 \%, 26.67$ and $27.50 \%$ and 30.97 and $25.89 \%$ for irrigation every 4-days 
Table 3. Effect of irrigation intervals, potassium silicate and seaweed extract treatments on flowering date (days), number of inflorescences/plant and inflorescence diameter (cm) of Tagetes patula plants during 2018 and 2019 seasons.

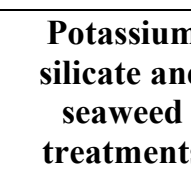

(B) $\begin{array}{lllll}\text { A1 } & \text { A2 } & \text { A3 } & \text { A4 } & \begin{array}{c}\text { Mean } \\ \text { (B) }\end{array}\end{array}$

First season (2018)
Irrigation intervals (A)

A1

A2

A3

A4

Mean

(B)

\begin{tabular}{|c|c|c|c|c|c|c|c|c|c|c|}
\hline \multicolumn{11}{|c|}{ Flowering date/days (first apparent flowering bud) } \\
\hline Control (water) & 74.5 & 70.4 & 67.5 & 62.3 & 68.7 & 75.7 & 74.2 & 69.2 & 64.4 & 70.9 \\
\hline PS1 & 73.6 & 68.0 & 66.3 & 64.1 & 68.0 & 75.1 & 74.7 & 64.8 & 65.7 & 70.1 \\
\hline PS2 & 71.5 & 73.5 & 69.4 & 65.2 & 69.9 & 73.4 & 71.6 & 63.7 & 60.3 & 67.3 \\
\hline SWE1 & 72.7 & 69.7 & 67.3 & 59.2 & 67.2 & 74.5 & 70.3 & 62.3 & 58.4 & 66.4 \\
\hline SWE2 & 69.3 & 65.3 & 62.5 & 58.4 & 63.9 & 72.3 & 68.2 & 61.5 & 57.7 & 64.9 \\
\hline PS2 + SWE2 & 68.4 & 63.3 & 58.5 & 55.9 & 61.5 & 69.1 & 62.7 & 60.6 & 57.2 & 62.4 \\
\hline Mean (A) & 71.7 & 68.4 & 65.3 & 60.9 & & 73.4 & 70.3 & 63.7 & 60.6 & \\
\hline L.S.D. at 5\% & \multicolumn{2}{|c|}{ A: 2.9} & B: 4.2 & \multicolumn{2}{|c|}{ AB: 8.4} & \multicolumn{2}{|c|}{ A: 3.1} & B: 3.7 & \multicolumn{2}{|c|}{ AB: 7.4} \\
\hline \multicolumn{11}{|c|}{ Number of inflorescences/plant } \\
\hline Control (water) & 12.3 & 10.4 & 8.7 & 7.2 & 9.7 & 12.8 & 10.8 & 9.3 & 8.4 & 10.3 \\
\hline PS1 & 12.7 & 10.5 & 9.1 & 7.4 & 9.9 & 13.3 & 13.0 & 10.4 & 9.1 & 11.5 \\
\hline PS2 & 14.5 & 11.3 & 9.7 & 9.3 & 11.2 & 13.5 & 13.5 & 10.8 & 10.3 & 12.0 \\
\hline SWE1 & 13.8 & 11.2 & 10.2 & 8.5 & 10.9 & 12.4 & 12.8 & 10.6 & 9.5 & 11.3 \\
\hline SWE2 & 14.7 & 13.4 & 11.4 & 9.3 & 12.2 & 15.1 & 14.1 & 12.5 & 9.7 & 12.9 \\
\hline PS2 + SWE2 & 15.7 & 14.5 & 13.1 & 10.7 & 13.5 & 16.3 & 14.9 & 13.2 & 11.3 & 13.9 \\
\hline Mean (A) & 14.0 & 11.9 & 10.4 & 8.7 & & 13.9 & 13.2 & 11.13 & 9.72 & \\
\hline L.S.D. at 5\% & \multicolumn{2}{|c|}{ A: 0.9} & B: 1.2 & \multicolumn{2}{|c|}{ AB: 2.4} & \multicolumn{2}{|c|}{ A: 1.1} & B: 0.9 & \multicolumn{2}{|c|}{ AB: 1.8} \\
\hline \multicolumn{11}{|c|}{ Inflorescences diameter (cm) } \\
\hline Control (water) & 3.3 & 3.1 & 2.7 & 2.1 & 2.8 & 2.9 & 3.0 & 2.4 & 1.9 & 2.6 \\
\hline PS1 & 3.5 & 3.2 & 2.9 & 2.3 & 3.0 & 3.1 & 3.2 & 2.7 & 2.2 & 2.8 \\
\hline PS2 & 3.7 & 3.5 & 3.4 & 2.8 & 3.4 & 3.4 & 3.5 & 3.2 & 2.7 & 3.2 \\
\hline SWE1 & 3.5 & 3.0 & 3.1 & 2.5 & 3.0 & 3.4 & 3.3 & 2.9 & 2.5 & 3.0 \\
\hline SWE2 & 3.8 & 3.7 & 3.5 & 2.7 & 3.4 & 3.6 & 3.5 & 3.3 & 2.9 & 3.3 \\
\hline PS2 + SWE2 & 4.1 & 4.1 & 3.8 & 3.1 & 3.9 & 4.3 & 3.7 & 3.7 & 3.2 & 3.7 \\
\hline Mean (A) & 3.7 & 3.4 & 3.2 & 2.6 & & 3.5 & 3.4 & 3.0 & 2.6 & \\
\hline L.S.D. at 5\% & A: & & B: 0.2 & & 0.4 & A: & & B: 0.2 & & 0.4 \\
\hline
\end{tabular}

A1: daily irrigation, A2: irrigating every two days, A3: every three days and A4: every four days. PS1: potassium silicate at $3 \mathrm{ml} / \mathrm{l}$, PS2: potassium silicate at $5 \mathrm{ml} / \mathrm{l}, \mathrm{SWE1}$ : seaweed at $3 \mathrm{ml} / \mathrm{l}, \mathrm{SWE2}$ : seaweed at $5 \mathrm{ml} / \mathrm{l}$. and PS2 + SWE2: potassium silicate at $5 \mathrm{ml} / \mathrm{l}+$ seaweed at $5 \mathrm{ml} / \mathrm{l}$. 
Table 4. Effect of irrigation intervals, potassium silicate and seaweed extract treatments on inflorescence fresh and dry weights (g) and vase life (days) of Tagetes patula plants during 2018 and 2019 seasons.

\begin{tabular}{|c|c|c|c|c|c|c|c|c|c|c|}
\hline \multirow{3}{*}{$\begin{array}{l}\text { Potassium } \\
\text { silicate and } \\
\text { seaweed } \\
\text { treatments } \\
\text { (B) }\end{array}$} & \multicolumn{10}{|c|}{ Irrigation intervals (A) } \\
\hline & $\mathbf{A 1}$ & & $\mathbf{A 3}$ & A4 & $\begin{array}{l}\text { Mean } \\
\text { (B) }\end{array}$ & A1 & A2 & $\mathbf{A 3}$ & A4 & $\begin{array}{c}\text { Mean } \\
\text { (B) }\end{array}$ \\
\hline & \multicolumn{5}{|c|}{ First season (2018) } & \multicolumn{5}{|c|}{ Second season (2019) } \\
\hline \multicolumn{11}{|c|}{ Inflorescence fresh weight (g) } \\
\hline Control (water) & 3.48 & 3.35 & 3.07 & 2.45 & 3.09 & 3.65 & 3.46 & 3.12 & 2.73 & 3.24 \\
\hline PS1 & 4.05 & 3.73 & 3.31 & 2.67 & 3.44 & 3.84 & 3.67 & 3.32 & 2.94 & 3.44 \\
\hline PS2 & 4.18 & 3.86 & 3.62 & 2.83 & 3.62 & 4.11 & 3.92 & 3.45 & 3.13 & 3.65 \\
\hline SWE1 & 3.55 & 3.42 & 3.16 & 2.44 & 3.14 & 3.78 & 3.55 & 3.15 & 2.81 & 3.32 \\
\hline SWE2 & 3.85 & 3.60 & 3.28 & 2.71 & 3.36 & 3.87 & 3.74 & 3.28 & 3.05 & 3.49 \\
\hline PS2 + SWE2 & 4.31 & 3.95 & 3.82 & 2.95 & 3.76 & 4.25 & 4.14 & 3.75 & 3.18 & 3.83 \\
\hline Mean (A) & 3.90 & 3.65 & 3.37 & 2.68 & & 3.92 & 3.75 & 3.35 & 2.97 & \\
\hline L.S.D. at $5 \%$ & \multicolumn{2}{|c|}{ A: 0.09} & B: 0.08 & \multicolumn{2}{|c|}{ AB: 0.16} & \multicolumn{2}{|c|}{ A: 0.06} & B: 0.11 & \multicolumn{2}{|c|}{ AB: 0.22} \\
\hline \multicolumn{11}{|c|}{ Inflorescence dry weight (g) } \\
\hline Control (water) & 0.38 & 0.39 & 0.33 & 0.30 & 0.35 & 0.36 & 0.34 & 0.31 & 0.26 & 0.32 \\
\hline PS1 & 0.44 & 0.42 & 0.35 & 0.32 & 0.38 & 0.38 & 0.37 & 0.34 & 0.27 & 0.34 \\
\hline PS2 & 0.47 & 0.45 & 0.38 & 0.35 & 0.41 & 0.42 & 0.39 & 0.37 & 0.32 & 0.38 \\
\hline SWE1 & 0.41 & 0.39 & 0.34 & 0.32 & 0.37 & 0.37 & 0.35 & 0.33 & 0.26 & 0.33 \\
\hline SWE2 & 0.45 & 0.42 & 0.36 & 0.34 & 0.39 & 0.39 & 0.37 & 0.36 & 0.31 & 0.36 \\
\hline PS2 + SWE2 & 0.52 & 0.48 & 0.39 & 0.35 & 0.44 & 0.49 & 0.46 & 0.41 & 0.32 & 0.42 \\
\hline Mean (A) & 0.45 & 0.43 & 0.36 & 0.33 & & 0.40 & 0.38 & 0.35 & 0.29 & \\
\hline
\end{tabular}

L.S.D. at 5\%

A: 0.03

B: 0.01

AB: 0.02

A: 0.02

B: 0.02

AB: 0.04

Vase life (days)

$\begin{array}{lcccccccccc}\text { Control (water) } & 10.2 & 9.8 & 8.6 & 6.4 & 8.8 & 9.8 & 9.4 & 9.2 & 7.4 & 9.0 \\ \text { PS1 } & 11.4 & 10.6 & 9.4 & 7.4 & 9.7 & 10.6 & 10.2 & 10.0 & 8.2 & 9.8 \\ \text { PS2 } & 11.8 & 11.2 & 10.2 & 8.2 & 10.4 & 11.6 & 10.8 & 10.6 & 8.8 & 10.5 \\ \text { SWE1 } & 10.6 & 10.4 & 9.2 & 7.8 & 9.5 & 10.8 & 10.2 & 9.8 & 7.8 & 9.7 \\ \text { SWE2 } & 11.6 & 10.8 & 9.6 & 8.4 & 10.1 & 11.4 & 11.0 & 10.4 & 8.4 & 10.3 \\ \text { PS2 + SWE2 } & 12.4 & 11.6 & 10.2 & 8.8 & 10.8 & 12.8 & 12.2 & 10.6 & 9.2 & 11.2 \\ \text { Mean (A) } & 11.3 & 10.7 & 9.5 & 7.8 & & 11.2 & 10.6 & 10.1 & 8.3 & \end{array}$

L.S.D. at 5\%
A: 1.1
B: 0.7

AB: 1.4

A: 0.8

B: 0.6

AB: 1.2

A1: daily irrigation, A2: irrigating every two days, A3: every three days and A4: every four days. PS1: potassium silicate at $3 \mathrm{ml} / \mathrm{l}$, PS2: potassium silicate at $5 \mathrm{ml} / \mathrm{l}, \mathrm{SWE1}$ : seaweed at $3 \mathrm{ml} / \mathrm{l}, \mathrm{SWE} 2$ : seaweed at $5 \mathrm{ml} / \mathrm{l}$, and PS2 + SWE2: potassium silicate at $5 \mathrm{ml} / \mathrm{l}+$ seaweed at $5 \mathrm{ml} / \mathrm{l}$. 
compared with daily irrigation in the first and second season, respectively. The earliest first apparent flowering bud has been obtained from the longest irrigation interval (60.9 and 60.6 days), while irrigation interval every day delayed the flowering date (71.7 and 73.4 days) in the $1^{\text {st }}$ and $2^{\text {nd }}$ seasons, respectively. Maximum number of inflorescences/plant (14.00 and 13.90) were resulted with daily irrigation followed by (11.90 and 13.20) at two days of irrigation interval, then, three days of irrigation interval (10.40 and 11.13), while four days interval produced minimum (8.70 and 9.72) number of inflorescences/plant in the $1^{\text {st }}$ and $2^{\text {nd }}$ seasons, respectively. These findings are in harmony with those of Abdel-Said et al. (2019) on Lilium longiflorum and Akhtar et al. (2019) on Calendula officinalis and Dianthus barbatus. It was notcied that various conditions of drought stress can have different effects on flowering, while drought sometimes results in barrenness during flowering (Farooq et al., 2009 and $\mathrm{Wu}$ et al., 2017). Jaimez et al. (2000) and BissuelBelaygue et al. (2002) found that in some ornamental plants, drought stress significantly affected flower aspects (number of aborted flowers, length of bulb inflorescence, and number of floral buds). The preliminary plant response to water stress which results in the decrease in photosynthesis rate is the closure of stomata to prevent transpirational water loss (Mahajan and Tuteja, 2005 and Mansfield and Atkinson, 1990). Subsequently, the decrease in the rate of photosynthesis would minimize flower formation and number (Salehi and Bahadoran, 2015). It seems that due to the reduction of photosynthesis and consequently the decrease of leaf area and the transfer of assimilated compounds to flowers, water stress will shorten the flowering perio (Jafarzadeh et al., 2013).

In relation to the other factor, the five tested stimulants, namely, potassium silicate or/and seaweed extract caused an increase in number inflorescences/plant, inflorescence diameter, inflorescence fresh and dry weights and vase life over those given by control treatment in both seasons as shown in Tables (3 and 4). These treatments hastened the first apparent flowering bud of tagetes plants. Using the two materials together was significantly preferable than using each substance alone in this respect. Tagetes produced maximum number of inflorescences/plant (13.50 and 13.90), maximum inflorescences diameter (3.90 and $3.70 \mathrm{~cm}$ ), maximum inflorescence fresh and dry weight (3.76 and 3.83 for fresh and 0.44 and $0.42 \mathrm{~g}$ for dry weight) and maximum vase life (10.80 and 11.20 days) at potassium silicate $5 \mathrm{ml} / 1+$ seaweed extract $5 \mathrm{ml} / 1$ in both seasons, respectively. However, the untreated plants produced the minimum values. Also, the earliest flowering was obtained from combination with two substances at high level (61.50 and 62.40 days).

Silicon's prevalent positive action on growth characteristics may be due to its essential roles in protecting plants from drought, cold, disease and fungal attack, relieving abiotic stress (salinity and toxicity of heavy metals), and enhancing root growth, water and nutrient uptake and plant pigments (Ma et al., 2001; Datnoff et. al., 2007 and Qin and Tian, 2009). These results are consistent with those obtained by Bayat (2013) on the impact of silicon on stimulating growth characteristics.

Seaweed extracts have stimulating effects on growth characteristics which may be due to its important action on improving cell division since it contains higher amounts of nutrients, namely $\mathrm{N}, \mathrm{Mg}, \mathrm{S}, \mathrm{P}, \mathrm{Cu}, \mathrm{K}, \mathrm{Mn}$, $\mathrm{Ca}, \mathrm{Mo}, \mathrm{Fe}$, and $\mathrm{B}$, natural hormones such as cytokinins, IAA and $\mathrm{GA}_{3}$, amino acids, vitamins and antioxidants (James, 1994 and Soliman et al., 2000). These components play an important role in protecting plant cells from damage and all plant stresses and improving the division of cells and organic food biosynthesis (Kulk, 1995 and Strick et al., 1997). These findings are in accordance with those obtained with regard to the impact of seaweed extracts on growth characteristics 
(Ragab, 2016 and Abdou et al., 2018). The progressive impact of silicon and seaweed extract on flowering time could be due to their vital role in in balancing the ratio between carbohydrates and nitrogen in favour of flowering (Soliman et al., 2000 and Neumann and Zur-Nieden, 2001).

Tables (3 and 4) show that the interaction between factor A (interval irrigation) and factor $\mathrm{B}$ (potassium silicate and/or seaweed) for flowering date, number of inflorescences per plant, inflorescences diameter and fresh and dry weights of inflorescence were significant in both seasons except for the irrigation interval every two days in comparison with plants irrigated daily. The highest overall values of flowering characters, were obtained from plants treated by dual dose of potassium silicate and seaweed in combination with the interval irrigation. However, no effect of this treatment was found on the flowering date.

\section{Essential oil percentage:}

In relation to irrigation intervals treatments, obtained results presented in Table (5) stated that no significant differences were detected among four ones for essential oil percentage in the two seasons. The highest values were given from plants irrigated daily $(0.067$ and $0.070 \%)$ in both the first and second seasons, respectively, while the minimum values were resulted from irrigation intervals at four days $(0.062$ and $0.064 \%)$ in the first season and in the second, respectively. The reduction in essential oil may be attributed to disturbance in carbohydrate and photosynthesis production under stress and suppression of the growth of plants (Flexas and Medrano, 2002). Similar results were observed for Cympobogon flexuosus under drought (Sangwan et al., 2002).

Supplying tagetes plants with combination of potassium silicate and SWE at high concentration, caused a significant

Table 5. Effect of irrigation intervals, potassium silicate and seaweed extract treatments on essential oil percentage of Tagetes patula plants during 2018 and 2019 seasons.

\begin{tabular}{|c|c|c|c|c|c|c|c|c|c|c|}
\hline \multirow{3}{*}{$\begin{array}{l}\text { Potassium } \\
\text { silicate and } \\
\text { seaweed } \\
\text { treatments } \\
\text { (B) }\end{array}$} & \multicolumn{10}{|c|}{ Irrigation intervals (A) } \\
\hline & A1 & $\mathbf{A 2}$ & $\mathbf{A 3}$ & A4 & $\begin{array}{c}\text { Mean } \\
\text { (B) }\end{array}$ & A1 & $\mathbf{A 2}$ & $\mathbf{A 3}$ & A4 & $\begin{array}{l}\text { Mean } \\
\text { (B) }\end{array}$ \\
\hline & \multicolumn{5}{|c|}{ First season (2018) } & \multicolumn{5}{|c|}{ Second season (2019) } \\
\hline \multicolumn{11}{|c|}{ Essential oil \% } \\
\hline Control (water) & 0.057 & 0.056 & 0.054 & 0.055 & 0.056 & 0.062 & 0.061 & 0.059 & 0.058 & 0.060 \\
\hline PS1 & 0.062 & 0.059 & 0.057 & 0.056 & 0.059 & 0.067 & 0.065 & 0.066 & 0.059 & 0.064 \\
\hline PS2 & 0.068 & 0.065 & 0.063 & 0.064 & 0.065 & 0.071 & 0.068 & 0.067 & 0.062 & 0.067 \\
\hline SWE1 & 0.065 & 0.062 & 0.062 & 0.060 & 0.062 & 0.069 & 0.070 & 0.065 & 0.065 & 0.067 \\
\hline SWE2 & 0.072 & 0.068 & 0.067 & 0.066 & 0.068 & 0.074 & 0.072 & 0.069 & 0.068 & 0.071 \\
\hline PS2 + SWE2 & 0.079 & 0.075 & 0.073 & 0.072 & 0.074 & 0.075 & 0.073 & 0.070 & 0.069 & 0.072 \\
\hline Mean (A) & 0.067 & 0.064 & 0.063 & 0.062 & & 0.070 & 0.068 & 0.066 & 0.064 & \\
\hline
\end{tabular}

L.S.D. at 5\%

A: N.S

B: 0.015

AB: N.S

A: N.S

B: 0.011

AB: N.S

A1: daily irrigation, A2: irrigating every two days, A3: every three days and A4: every four days. PS1: potassium silicate at $3 \mathrm{ml} / \mathrm{l}$, PS2: potassium silicate at $5 \mathrm{ml} / \mathrm{l}, \mathrm{SWE} 1$ : seaweed at $3 \mathrm{ml} / \mathrm{l}, \mathrm{SWE2}$ : seaweed at $5 \mathrm{ml} / \mathrm{l}$, and PS2 + SWE2: potassium silicate at $5 \mathrm{ml} / \mathrm{l}+$ seaweed at $5 \mathrm{ml} / \mathrm{l}$. 
increase in the percentage of essential oil compared with control treatment in the two experimental seasons as shown in Table (5). The increase in the essential oil percentage when tagetes plants may be due to the higher energy in synthesis of biochemical metabolites as a result to applied seaweed extract. These findings are in harmony with those mentioned by El-Leithy et al. (2019) who found that using the seaweed extract significantly increased all the studied characters of essential oil and chemical constituents of Plectuanthus amboinicus (Lour). The capability of $\mathrm{Si}$ in promoting essential oil percentage was stated by Waly et al. (2019) on Rosmarinus officinalis L.

The interaction between the two factors $(\mathrm{A} \times \mathrm{B})$ treatments was no significant for essential oil $\%$ as compared with the control treatment in both seasons. The high percentages were obtained due to potassium silicate + seaweed extract at high concentration for plants irrigated daily as recorded $0.079 \%$ in the first season and $0.075 \%$ in the second season, respectively.

It could be recommended that to reduce the effect of drought stress, suppling Tagetes patula plants with $5 \mathrm{ml} / 1$ of seaweed extract and/or potassium silicate to obtain the best growth characteristics, oil percentage and vase life.

\section{REFERENCES}

Abdel-Said, Z.H.R.; Bazaraa, W.M. and Nabih, A. (2019). Effect of amino acid (threonine), irrigation levels and their interaction on growth, flowering, bulbs productivity and chemical constituents of Lilium longiflorum, Thunb. plant. Mid. East J. of Agric. Res., 8(1):153-166.

Abdou, M.A.H.; Badran, F.S.; Ahmed, E.T.; Taha, R.A. and Abdel-Mola, M.A.M. (2018). Effect of Compost and Some Natural Stimulant Treatments on: II. Corms Production and Chemical Constituents of Gladiolus grandiflorus cv. Peter Pears Plants. Proc. of The $4^{\text {th }}$ Conf. of SSFOP, Scientific J. Flowers \& Ornamental Plants, 5(2):115-126.
Ahmadi Azar, F.; Hasanloo, T. and Feizi, V. (2015) Water stress and mineral zeolite application on growth and some physiological characteristics of mallow (Malva sylvestris). Journal of Plant Researches, 28(3):459-474.

Akhtar, G.; Rajwana, I.A.; Farid, N.; Younas, M.; Sajjad, Y.; Amin, M.; Razzaq, K. and Ullah, S. (2019). Effect of irrigation intervals on growth of annual flowers under climatic conditions of South Punjab, Pakistan. Pure Appl. Biol., 8(4):2169-2177.

Al-Ubaydi, R.M.; Al-Shakry, E.F.; AlSamara, M.A. and Al-Mohmadawy, S.M. (2017). Effect of irrigation intervals on growth, flowering and fruits quality of okra Abelmoschus esculentus (L.) Monech. Afric. J. of Agric. Res., 12(23):2036-2040.

Asif, M. (2008). Effect of Various NPK Levels on Growth, Yield and Xanthophyll Contents of Marigold. MSc. Thesis., Inst. Hort. Sci., Univ. Agric., Faisalabad, Pakistan, 95 p.

Battacharyya, D.; Babgohari, M.Z.; Rathor, P. and Prithiviraj, B. (2015). Seaweed extracts as biostimulants in horticulture. Sci. Hortic., 30(196):39-48.

Bayat, H.; Alirezaie, M.; Neamati, H. and Saadabad, A.A. (2013). Effect of silicon of growth and ornamental traits of saltstressed calendula (Calendula officinalis). J. of Ornamental Plants, 3(4):207-214.

Bhaskar, N. and Miyashita, K. (2005). Lipid composition of Padina tetratomatica (Dictyotales pheophyta), a brown seaweed of the West Coast of India. Ind. J. Fisheries., 52(3):263-268.

Bissuel-Belaygue, C.; Cowan, A.A.; Marshall, A.H. and Wery, J. (2002). Reproductive development of white clover (Trifolium repens L.) is not impaired by moderate water deficit that reduces vegetative growth. Crop Science, 42:406-414. 
Chen, W.; Yao, X.; Cai, K. and Chen, J. (2010). Silicon alleviates drought stress of rice plants by improving plant water status, photosynthesis and mineral nutrient absorption. Biological Trace Element Research, 142:67-76.

Chowdhury, M.S.H.; Koike, M.; Muhammed, N.; Halim, M.A.; Saha, N. and Kobayashi, H. (2009). Use of plants in healthcare; a traditional ethnomedicinal practice in rural areas of Southeastern Bangladesh. Int. J. of Bio. Div. Sci. and Man., 5(1):41-51.

Datnoff, L.E.; Rodrigues, F. and Seebold, K. (2007). Silicon and plant disease. In: Datnoff, L.E.; Elmer, W.H. and Huber, D. (eds.), Mineral Nutrition and Plant Disease, American Phytophythiological Society, St. Paul, MN., pp. 233-246.

Dole, J.M.; Carlson, A.S.; Crawford, B.D. and McCall, I.F. (2013). Vase life of new cut flowers. Acta Horticulture, 1000:6370.

Ehdaie, B. (1995). Variation in water use efficiency and its components in wheat: II. Pot and field experiment. Crop. Sci., 35(6):1617-1626.

El-Leithy, A.S.; El-Attar, A.B.E.; ElGhadban, E.A.E. and Abdel-Ghani, N.M. (2019). Effect of salinity, seaweed extract and salicylic acid on growth, essential oil and chemical composition of Plectranthus amboinicus (Lour). Journal Bioscience Research, 16(1):118-133.

Farooq, M.; Wahid, A.; Kobayashi, N.; Fujita, D. and Basra, S.M.A. (2009). Plant drought stress: effects, mechanisms and management. In: Lichtfouse, E.; Navarrete, M.; Debaeke, P.; Véronique, S. and Alberola, C. (eds.), Sustainable Agriculture, Springer, Dordrecht, pp. 153-188.

Flexas, J. and Medrano, H. (2002). Droughtinhibition of photosynthesis in $\mathrm{C} 3$ plants: stomatal and nonstomatal limitations revisited. Ann. Bot., 89:183-189.
Guenther, E. (1961). The Essential Oils, $4^{\text {th }}$ Ed., Vol. III. D. Van Nostrand Comp., New York, London.

Hemida, K.A.; Ali, R.M. and Ibrahim, W.M. (2015). Enhance salt stress tolerance in wheat (Triticum aestivum L.) plant using exogenous $\beta$-carotene or algal extract. Intern. J. of Biomed. Sci. \& Bioinform., 2(1):26-32

Hussein, H.A.; Metwally, A.K.; Farghaly, K.A. and Bahawirth, M.A. (2011). Effect of irrigation interval (water stress) on vegetative growth and yield in two genotypes of okra. Aus. J. of Basic and Appl. Sci., 5(12):3024-3032.

Jackson, M.L. (1973). Soil Chemical Analysis. Prentice-Hall of India Private Ltd. M-97, New Delhi, India, 498 p.

Jafarzadeh, L.; Omidi, H. and Bostani, A. (2013). Effect of drought stress and biofertilizer on flower yield, photosynthesis pigments and proline content of marigold (Calendula officinalis L.). Iran. J. of Medicinal and Aromatic Plants, 29(3):666-680.

Jaimez, R.E.; Vielma, O.; Rada, F. and Garcia-Nuñes, C. (2000). Effects of water deficit on the dynamics of flowering and fruit production in Capsicum chinense Jacq in a tropical semiarid region of Venezuela. Journal of Agronomy and Crop Science, 185:113119.

James, B. (1994). Chapters from life. Ann. Rev. Physiol. Plant. Mol. Biolog., 4:1-23.

Jugal, K. and Ramani, P.V. (2017). Effect of silicon on nitrogen use efficiency, yield and $\mathrm{N}$ and $\mathrm{Si}$ contents in rice under loamy sand soil. Malav. Research J. Chem. and Environ., 21(4):110-118.

Korndörfer, G.H. and Lepsch, I. (2001). Effect of silicon on plant growth and crop yield. In: Datnoff, L.E.; Snyder, G.H. and Korndörfer, G.H. (eds.), Silicon in Agriculture (Vol. 8) Studies in Plant Science, Elsevier, Amsterdam, pp. 133147. 
Kulk, M.M. (1995). The potential cyanobacteria (blue green algae) for using in the biological control of plant, pathogenic bacteria and fungi. European J. of Plant Pathology, 101(6):585-599.

Lawrence, B.M. (1985). Essential oils of Tagetes genus. Perfum. Flavor., 10(5):73-82.

Liang, Y.; Sun, W. and Christie, P. (2007). Mechanisms of silicon-mediated alleviation of abiotic stresses in higher plants: A review. Environ. Poll., 147(2):422-428.

Ma, J.F. (2004). Role of silicon in enhancing the resistance of plants to biotic and abiotic stresses. Soil Sci. \& Plant Nutr., 50(1):11-18.

Ma, J.F.; Miyake, Y.; and Takahashi, E. (2001). Silicon as a beneficial element for crop plants. In: Datnoff, L.E.; Snyder, G.H. and Korndorfer, G.H. (eds.), Silicon in Agriculture, Studies in Plant Science, Elsevier, Amsterdam, pp. 17-39.

Mahajan, S. and Tuteja, N. (2005). Cold, salinity and drought stresses: An overview. Archives of Biochemistry and Biophysics, 444 (2):139-158.

Manivannan, P.; Abdul Jaleel, C.; Kishorekumar, A.; Sankar, B.; Somasundaram, R.; Sridharan, R. and Panneerselvam, R. (2007). Changes in antioxidant metabolism of Vigna unguiculata (L.) Walp. by propiconazole under water deficit stress. Colloids and Surfaces B: Biointerfaces, 57(1):69-74.

Mansfield, T.A. and Atkinson, C.J. (1990). Stomatal behavior in water stressed plants. In: Alscher, R.G. and Cumming, J.R. (eds.), Stress Responses in Plants: Adaptation and Acclimation Mechanisms, Wiley-Liss, New York, pp. 241-264.

Mead, R.; Currow, R.N. and Harted, A.M. (1993). Statistical Methods in Agricultural and Experimented Biology. $2^{\text {nd }}$ Ed. Chapman and Hall, London, 472 $\mathrm{p}$
Moustafa, H.E.B.; Ahmed, S.S. and Shahin, S.M. (2018). Effect of foliar spray with potassium silicate on growth and active constituents of horseradish armiractetra (Moringa oleifera Lam.) plants grown in some soils of Egypt. Middle East J. of Agric. Res., 7(1):60-70.

MSTAT-C (1986). A Microcomputer program for the Design Management and Analysis of Agronomic Research Experiments (version 4.0), Michigan State Univ., U.S.A.

Nau, J. (1997). Tagetes (marigold). In: Ball, V. (ed.), Ball Redbook, Ball Publishing, Batavia, IL., USA, pp. 763-766.

Neumann, D. and Zur-Nieden, U. (2001). Silicon and heavy metal tolerance of higher plants. Phytochemistry, 56:685692.

Owies, T.; Zhang, H. and Pala, M. (2000). Water use efficiency of rainfed and irrigated bread wheat in Mediterranean environments. Agron. J., (92):231-238.

Qin, Z. and Tian, S.P. (2009). Enhancement of biocontrol activity of Cryptococcus laurentii by silicon and the possible mechanisms involved. Phytopathology, 95:69-75.

Ragab, T.M.E. (2016). Effect of Application of Seaweed Extracts on Growth and Quality of Some Ornamental Plants. M.Sc. Thesis, Fac. Agric., Ain Shams Univ., Egypt, 87 p.

Regina, D. and Katarzyna, W. (2011). The effect of silicon foliar application on the development of seasonal ornamental plants. Acta Agrotanica, 64(4):99-106.

Romero, M.R.; Opens, A.; Jurado, O. and Cuartero, J. (2006). Silicon alleviates the deleterious salt effect on tomato plant growth by improving plant water status. J. Plant Physiol., 163(8):847-855.

Salehi, H. and Bahadoran, M. (2015). Growth and flowering of two tuberose (Polianthes tuberosa L.) cultivars under deficit irrigation by saline water. Journal 
of Agricultural Science and Technology, 17(2):415-426.

Sangwan, R.S.; Farooqi, A.H.A.; Bansal, R.P. and Neelam, S.S. (2002). Interspecific variation in physiological and metabolic responses of five species of Cymbopogon to water stress. Jour Plant Physiol., 142:618-22.

Soliman, A.I.I.; Hussein, M.H.; Dessouki, S.A.S. and Torky, Y. (2000). Production of phytohormones by using some blue green algae used as soil inoculants for rice fields in Egypt. J. Union Arab Biol., Cairo, Physiology and Algae, 88:83-102.

Strick, W.A.; Staden, J.V. and Van-Staden, J. (1997). Screening of some South African seaweeds for cytokinin like activity. South Africa J. Botany, 63(3):161-164.

Waly, A.A.; Abd El-Fattah, Y.M.; Hassan, M.A. and El-Ghadban, E.A.E.(2019).
Effect of foliar spraying with seaweeds extract, chitosan and potassium silicate on Rosmarinus officinalis L. plants in sandy soil. Scientific J. Flowers \& Ornamental Plants, 6(3):191-209.

Wu, P.; Wu, C. and Zhou, B. (2017). Drought stress induces flowering and enhances carbohydrate accumulation in Averrhoa carambola. Horticultural Plant Journal, 3(2):60-66.

Yazdani, F.; Allahdadi, I.; Akbari, G.A. and Behbahani, M.R. (2007). Effect of different rates of superabsorbent polymer (Tarawat A200) on soybean yield and yield components. Pajouhesh and Sazandegi, 75: 167-174.

\section{إستجابة نباتات القطيفة للرش الورقي بسيليكات البوتاسيوم ومستخلص الأعشاب البحرية تحت فترات الري المختلفة الئيوم

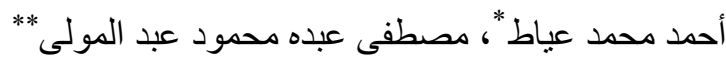

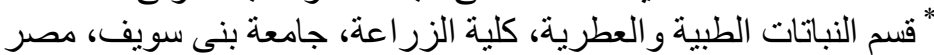

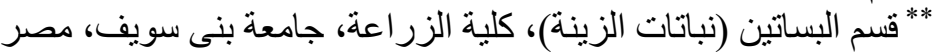

تم اجر اء هذه الدراسة في مدينة سمسطا بمحافظة بني سويف، جمهورية مصر العربية، خلال الموسمين المتعاقبين

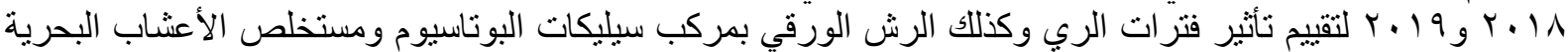

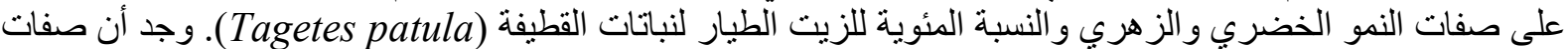

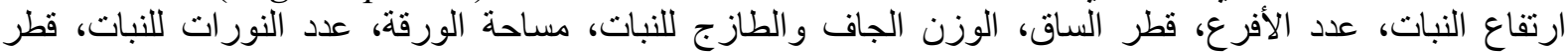

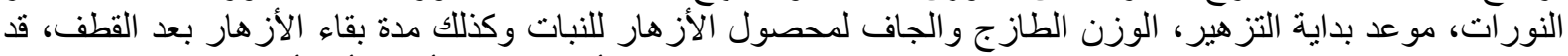

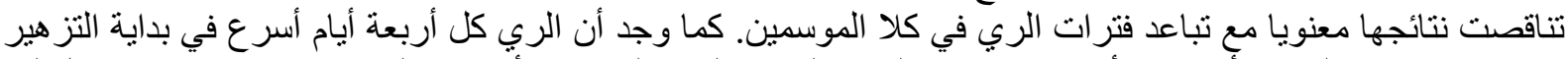

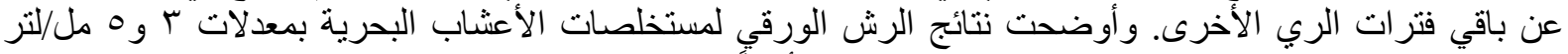

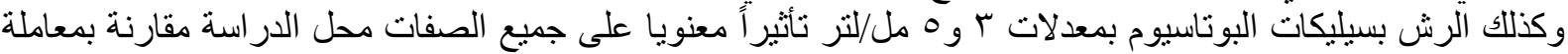

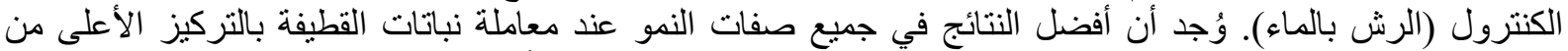

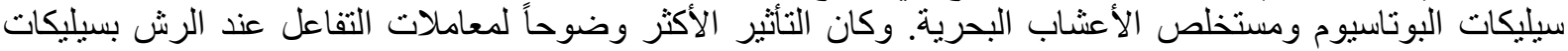

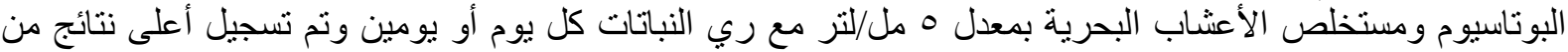

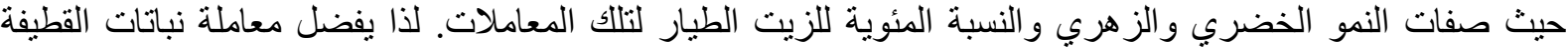

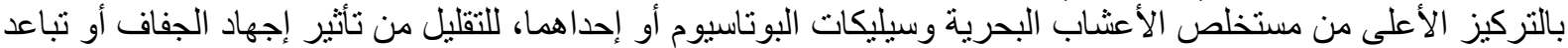

